\title{
A avaliação da inteligência: questões contemporâneas, contribuições teóricas e uso de instrumentos
}

\author{
Tatiana P. Mecca - Universidade Presbiteriana Mackenqie, São Paulo/SP, Brasil
}

Flanagan, D. P. \& Harrison, P. L. (Orgs.). (2012). Contemporary intellectual assessment: theories, tests and issues. $3^{\text {a Ed. Vova }}$ Iorque, NK: The Guilford Press.

A inteligência pode ser considerada um dos construtos mais tradicionais em avaliação psicológica. Formas para avaliá-la têm sido consistentemente documentadas ao longo da história da psicologia em razão dos avanços nas concepções teóricas e empíricas a cerca de sua estrutura. Nesse sentido, os autores Dawn P. Flanagan e Patti L. Harrison organizaram a Terceira Edição da obra Contemporary intellectual assessment: theories, tests and issues, a qual apresenta 36 capítulos elaborados por pesquisadores atualmente considerados referências internacionais no tema. Os capítulos encontram-se subdivididos em seis grandes eixos, sendo eles: 1) The origins of intellectual assessment; 2) Contemporary theoretical perspectives, 3) Contemporary intelligence, cognitive and neuropsychological batteries (and associated achievement tests); 4) Contemporary interpretative approaches and their relevance for intervention; 5) Assessment of intelligence and cognitive functioning in different populations; e 6) Contemporary and emerging issues in intellectual assessment.

O primeiro eixo é composto por dois capítulos: "A history of intelligence assessment" de John D. Wassrman; e "A bistory of intelligence test interpretation" de Randy W. Kamphaus, Anne Pierce Winsor, Ellen W. Rowe e Sangwon Kim. São apresentadas as raízes históricas acerca do desenvolvimento e interpretação dos testes de inteligência até a evolução para os conceitos e práticas atuais, bem como as bases para o aprimoramento das abordagens subjacentes à interpretação dos resultados da testagem.

Em seguida, o segundo eixo, relacionado às perspectivas teóricas contemporâneas, é contemplado em sete capítulos: "Foundations for better understanding of cognitive abilities", de John L. Horn e Nayena Blankson; "The Cattel-Horn-Carroll Model of Intelligence", de W. Joel Schneider e Kevin S. McGrew; "Assessment of Intellectual Profile", de Jie-Qi Chen e Howard Gardner; "The thiarchic theory of successful intelligence", de Robert J. Sternberg, e, por fim, "Planning, attetion, simultaneous, sucessive: a cognitive-processing-based theory of intelligence", de Jack A. Naglieri, J. P. Das e Sam Goldstein. Nessa sessão, diversos modelos teóricos são apresentados como reflexos dos avanços em diversas áreas, a saber, a psicometria, a neuropsicologia e a psicologia cognitiva. A partir dessas três perspectivas, os autores discutem como as evidências empíricas dão suporte aos modelos, bem como as formas de operacionalização e aplicação destes.

Já a terceira parte do livro é a mais abrangente, composta por onze capítulos, em que cada um referese a uma bateria específica de avaliação. Os autores apresentam as características relevantes das principais baterias atualmente utilizadas para avaliar o funcionamento intelectual ou o perfil cognitivo. Acrescentam-se os estudos recentes de evidências de validade e fidedignidade dos testes, bem como as bases para interpretação dos mesmos. As escalas aqui revisadas são: "The Wechsler Adult Intelligence S cale - fourth edition and the Wechsler Memory Scale - fourth edition", de Lisa Whipple Drozdick e colaboradores; "The Wechsler Preschool and Primary Scale of Intelligence - third edition, the Wechsler Intelligence Scale for Children - fourth edition, and the Wechsler Individual Achievement Test - third edition", de Dustin Wahlstro e colaboradores; "The Stanford-Binet Intelligence Scale, fifth edition", de Gale H. Roid e Mark Pomplun; "The Kaufman Assessment Battery for Children second edition and the Kaufman Test of Educational Achievement - second editon", de Jennie Kaufman Singer e colaboradores; "The Woodcock-Johnson III Normative Update: Tests of Cognitive Abilities and Tests of Achievement", de Frederick A. Shrank e Barbara J Wendling; "The Differential Ability Scales - second edition", de Colin D. Elliot; "The Universal Nonverbal Intelligence Test", de R. Steve McCallum e Bruce A. Bracken; "The Cognitive Assessment System: from theory to practice", de Jack A. Naglieri e Tulio M. Otero; "The Reynolds Intellectual Assessment Scales and the Reynolds Intellectual Screening Test", de Cecil R. Reynolds, Randy W. Kamphaus e Tara C. Raines; "The Nepsy-II", com autoria de Robb N. Matthews, Cynthia A. Riccio e John L. Davis; e, por fim, "The Wechsler Nonverbal Scale of Ability: Assessment of Diverse Population”, também de Jack A. Naglieri e Tulio M. Otero.

Em seguida, a quarta sessão apresenta as abordagens contemporâneas para as interpretações dos testes de inteligência, bem como sua relevância para propostas e planejamentos de intervenções em uma intersecção com a neuropsicologia e os modelos cognitivos para compreensão de habilidades. São apresentadas as contribuições da avaliação de inteligência para a prática, bem como seu uso para 
diagnóstico, e modificações e adaptações nos procedimentos de testagem diante de condições específicas. Entre os cinco capítulos que fazem parte desse tema, estão: "The Cross-Battery Assessment approach: an overview, historical perspective, and current directions", de Dawn P. Flanagan, Vincent C. Alfonso e Samuel O. Ortiz; "Cognitive bypothesis testing: linking test results to the real world", de Catherine A. Fiorello, James B. Hale e Kirby L. Wycoff; "Processing approaches to interpretation of information from cognitive ability tests: a critical review", de Randy G. Floyd e John H. Kranzler; "Testing with culturally and linguistically diverse populations: moving beyond the verbal-performance dichotomy into evidence-based practice", de Samuel O. Ortiz, Salvador Hector Ochoa e Agnieszka M. Dynda; e 'Linking cognitive abilities to academic interventions for students with specific learning disabilities", de Nancy Mather e Barbara J. Wendling.

$\mathrm{O}$ quinto eixo é destinado à discussão de especificidades subjacentes a avaliação de inteligência e do funcionamento cognitivo em diferentes populações. São discutidas as especificidades no uso de testes para obtenção de perfis cognitivos em grupos clínicos: "Cognitive assessment in early childhood: theoretical and practice perspectives", de Laurie Ford, Michelle L. Kozey e Juliana Negreiros; "Use intelligence tests in the identification of giftedness", de David E. McIntosh, Felicia A. Dixon e Eric E. Pierson; "use the ability tests in the identification of specific learning disabilities within the context of an operational definition", de Dawn P. Flanagan e colaboradores; "Assessment of intellectual functioning in autism spectrum disorder", de Laura Grofer Klinger e colaboradores; "Cognitive and neuropsychological assessment of individuals with sensory and physical disabilities and traumatic brain injury", de Scott L. Decker, Julia A. Englund e Alycia M. Roberts; $\mathrm{e}$, por fim, "Use of intelligence tests in the identification of children with intellectual and developmental disabilities", de
Kathleen Armstrong, Jason Hangauer e Joshua Nadeau.

A última sessão apresenta abordagens contemporâneas relacionadas aos estudos a despeito da inteligência, como análises mais robustas utilizadas em pesquisas que objetivam verificar evidências de validade dos testes até sua relação com outros construtos neuropsicológicos, tais como as funções executivas. Seis capítulos compõem este eixo: "Using the joint test standards to evaluate the validity evidence for intelligence tests", de Jeffery P. Braden e Bradley C. Niebling; "Using confirmatory factor analysis to aid in understanding the constructs measured by intelligence tests", de Timothy Z. Miler e Matthew R. Reynolds; "The emergence of neuropsychological constructs into tests of intelligence and cognitive abilities", de Daniel C. Miler e Denise E. Maricle; "The role of cognitive and intelligence tests in the assessment of executive functions", de Denise E. Maricle e Erin Avirett; "The intelligence tests in the context of emerging assessment practices: problem-solving applications", de Brown-Chidsey e Kristina Andren; "Intellectual, cognitive and neuropsychological assessment in threetier service delivery systems in schools", de George McCloskey e colaboradores. Por fim, há um apêndice escrito por John B. Carroll sobre sua Teoria dos Três Estratos das Habilidades Cognitivas, no qual apresenta o modelo que propôs e a forma de operacionalização deste, aplicações práticas e futuras direções para avanços na investigação sobre o tema.

Trata-se de obra atual onde são contemplados os aspectos conceituais e práticos da avaliação da inteligência, desde os estudos iniciais da psicometria até a contemporaneidade, com modelos a respeito do funcionamento cognitivo. Possui relevância no contexto do ensino para estudantes de graduação e pós-graduação, pesquisadores e psicólogos clínicos que utilizam instrumentos em sua prática.

Sobre a autora:

Tatiana P. Mecca é psicóloga, mestre e doutoranda pelo Programa de Pós-Graduação Stricto Sensu em Distúrbios do Desenvolvimento da Universidade Presbiteriana Mackenzie, com Doutoramento Sanduíche pela Universidade de Coimbra, bolsista da Fundação de Amparo à Pesquisa do Estado de São Paulo - FAPESP. É professora convidada do Programa de Pós-Graduação Lato Sensu em Psicopedagogia em Neurociências e Psicologia Aplicada da Universidade Presbiteriana Mackenzie.

Contato com a autora:

E-mail: tati.mecca@gmail.com 